\title{
Effect of Raised Bed Sowing of Pigeon Pea in Vertisols in Central Narmada Valley Agro-Climatic Zone of Madhya Pradesh, India
}

\author{
Prashant Shrivastava, Yati Raj Khare*, Aashutosh Sharma and D.K. Pahalwan
}

Krishi Vigyan Kendra, Narsinghpur (M.P.), India

*Corresponding author

\section{A B S T R A C T}

\begin{tabular}{|l|}
\hline Ke y w o r d s \\
Pigeon pea, \\
Vertisols, Raised \\
bed
\end{tabular}

\section{Introduction}

Narsinghpur district of Madhya Pradesh is a major pulse producing district of the country. The pigeon pea of Gadarwara block of the district has made a niche for itself in the pulse market in the country. In the year 2013-14 pigeon pea was sown in 41700 ha area in the district (NABARD PLP 2016-17 of Narsinghpur; pp: 6). Narsinghpur is centrally located in India and is one of the beneficiary districts of river Narmada. Majority of the soil type of the district is vertisol - well known for its shrinking and swelling properties. When the moisture content reduces the soil shrinks following which deep cracks are developed in the soil surface. The same soil when irrigated gets swelled. These soils have drainage problems. The average annual rainfall of the district is $1006 \mathrm{~mm}$. Over the years the monsoon has been irregular in the district. During the year 2011-12 the total rainfall in the district was $1002.2 \mathrm{~mm}$ which rose to $1739.6 \mathrm{~mm}$ during 2012-13, and then reduced to $822.0 \mathrm{~mm}$ during 2013-14 (NABARD PLP 2016-17 of Narsinghpur; pp: 6). There have been instances when the rains fell incessantly for a few days creating a problem of water logging in the vertisiol areas. The pigeon pea crop suffers due to this condition of water logging. There is a usual practice of flatbed sowing of pigeon pea in the district. This aggravates the situation. In view of the above problem an assessment of raised bed sowing of pigeon pea was done during the year 201415 and 2015-16. 


\section{Materials and Methods}

The assessment was done on one acre fields of five farmers each in year 2014-15 and 201516. A tractor drawn bed planter was used for raised bed sowing of pigeon pea during kharif season. Pigeon pea variety TJT-501 was used for the study. Seed rate was kept as $10 \mathrm{~kg} / \mathrm{ha}$. The row to row distance was kept as $75 \mathrm{~cm}$.

The crop yield was calculated on actual yield results. Cost of cultivation was estimated based on prevalent market rates. The prevalent market rates were considered for the calculation of gross return. In the end Benefit: Cost ratio was calculated as ratio of average gross return and average gross cost.

\section{Results and Discussion}

The raise bed sowing of pigeon pea showed very good results. During the year 2014-15, under the flat bed sowing the crop yield was just $8.5 \mathrm{q} / \mathrm{ha}$ which improved to $14.5 \mathrm{q} / \mathrm{ha}$ under the raise bed sowing. Thus a yield increase of nearly $70 \%$ was observed under the raised bed sowing. This increase in yield can be attributed to the better management of rainwater in the raised beds. Another factor was the dismal performance of the flat bed sowing. The average cost of cultivation under the flat bed sowing was Rs. 22000/- per ha whereas it was Rs. 23500/- per ha. under the raised bed sowing. The prevalent market rate of the pigeon pea so produced was Rs. 5600/per quintal. Thus flatbed sown pigeon pea fetched at gross return of Rs. 47600/- per hectare whereas the raised bed sown crop fetched a gross return of Rs. 81200/- per hectare. The net return under the raised bed sowing was higher by Rs. 32170/- per hectare against the flat bed sowing. The Benefit Cost ratio was 2.16 in the case of flatbed sowing and was 3.45 under the raised bed sowing. Overall the performance of raised bed sowing of pigeon pea was far better that the performance of the flat bed sown pigeon pea.

During the year 2015-16 under the flat bed sowing the crop yield was just $11.00 \mathrm{q} / \mathrm{ha}$ which improved to $15.96 \mathrm{q} / \mathrm{ha}$ under the raise bed sowing. The average cost of cultivation under the flat bed sowing was Rs. 22400/- per ha whereas it was Rs. 23500/- per ha. under the raised bed sowing. The prevalent market rate of the pigeon pea so produced was Rs. $6000 /-$ per quintal. Thus flatbed sown pigeon pea fetched at gross return of Rs. 66000/whereas the raised bed sown crop fetched a gross return of Rs. 95760/- per ha. Net return under the raised bed sowing was72260/- per ha against Rs. 43600/- per ha under the flat bed sowing. The Benefit - Cost ratio was 4.07 under the raised bed sowing whereas it was 2.94 in the case of flatbed sowing. Overall the performance of raised bed sowing of pigeon pea was far better that the performance of the flat bed sown pigeon pea.

Table.1 Effect of raised bed sowing on the yield of pigeon pea (year 2014-15)

\begin{tabular}{|l|c|c|c|c|c|}
\hline Pigeon pea & $\begin{array}{c}\text { Yield } \\
\text { Q/ha }\end{array}$ & $\begin{array}{c}\text { A verage Cost } \\
\text { of cultivation } \\
\text { (Rs/ha) }\end{array}$ & $\begin{array}{c}\text { Average } \\
\text { Gross return } \\
\text { (Rs/ha) }\end{array}$ & $\begin{array}{c}\text { A verage } \\
\text { Net Return } \\
\text { (Rs/ha) }\end{array}$ & $\begin{array}{c}\text { Benefit Cost ratio } \\
\text { (Average gross } \\
\text { return / Average } \\
\text { gross cost) }\end{array}$ \\
\hline $\begin{array}{l}\text { Flat bed } \\
\text { sowing }\end{array}$ & 8.5 & 22000 & 47600 & 25600 & 2.16 \\
\hline $\begin{array}{l}\text { Raised bed } \\
\text { sowing }\end{array}$ & 14.5 & 23500 & 81200 & 57770 & 3.45 \\
\hline
\end{tabular}


Table.2 Effect of raised bed sowing on the yield of pigeon pea (year 2015-16)

\begin{tabular}{|l|c|c|c|c|c|}
\hline Pigeon pea & $\begin{array}{c}\text { Yield } \\
\text { Q/ha }\end{array}$ & $\begin{array}{c}\text { A verage Cost } \\
\text { of cultivation } \\
\text { (Rs/ha) }\end{array}$ & $\begin{array}{c}\text { Average } \\
\text { Gross } \\
\text { return } \\
\text { (Rs/ha) }\end{array}$ & $\begin{array}{c}\text { Average } \\
\text { Net Return } \\
\text { (Rs/ha) }\end{array}$ & $\begin{array}{c}\text { Benefit Cost ratio } \\
\text { (Average gross } \\
\text { return / A verage } \\
\text { gross cost) }\end{array}$ \\
\hline Flat bed sowing & 11.00 & 22400 & 66000 & 43600 & 2.94 \\
\hline Raised bed sowing & 15.96 & 23500 & 95760 & 72260 & 4.07 \\
\hline
\end{tabular}

Table.3 Average of the two years (2014-15 and 2015-16) of the performance of pigeon pea under raised bed sowing

\begin{tabular}{|l|c|c|c|c|c|}
\hline Pigeon pea & $\begin{array}{c}\text { Yield } \\
\text { Q/ha }\end{array}$ & $\begin{array}{c}\text { A verage Cost } \\
\text { of cultivation } \\
\text { (Rs/ha) }\end{array}$ & $\begin{array}{c}\text { A verage } \\
\text { Gross } \\
\text { return } \\
\text { (Rs/ha) }\end{array}$ & $\begin{array}{c}\text { A verage } \\
\text { Net Return } \\
\text { (Rs/ha) }\end{array}$ & $\begin{array}{c}\text { Benefit Cost ratio } \\
\text { (Average gross } \\
\text { return / A verage } \\
\text { gross cost) }\end{array}$ \\
\hline Flat bed sowing & 9.75 & 22200 & 56800 & 34600 & 2.55 \\
\hline Raised bed sowing & 15.23 & 23500 & 88480 & 65015 & 3.76 \\
\hline
\end{tabular}

The average of the two years was worked out and is presented in Table 3. It is well clear from the table that the raised bed sowing performed well in both the years of assessment.

The raised bed sowing is a very good tool for rainwater management in the vertisols. In the present study, with higher yields and higher benefit-cost ratio, the raised bed sowing of pigeon pea gave very good results as compared to the flat bed sowing. Low infiltration and poor surface drainage in vertisols developed water logging conditions thereby affecting initial plant population and crop performance under the flat bed sowing. The same got nullified under the raised bed sowing. Singh et al., (2014) in their study on pigeon pea on raised beds have also reported increasing trends in terms of crop yield. Sadvadiya et al., (2017) in their experiment on Indian bean have also reported that the raised bed method of sowing was found significantly superior over flatbed planting. Thus it can be concluded that the raised bed method of sowing of pigeon pea is a good tool for rain water management in vertisols and for increasing crop yield.

\section{References}

Singh, R.K., V.B. Singh, A.K. Singh and R. R. Singh (2014). Frontline demonstration: a productivity enhancement and technology dissemination tool for pigeon pea in eastern UP. International Journal of Farm Sciences, 4(3): 195-200, 2014.

Sodavadiya, H.B., V.R. Naik and S.D. Choudhary (2017) Effect of land configuration, irrigation and INM on growth, yield and water use efficiency of Indian bean (var.GNIB-21). International Journal of Current Microbiology and Applied Science (2017) 6(7): 2624-2630.

\section{How to cite this article:}

Prashant Shrivastava, Yati Raj Khare, Aashutosh Sharma and Pahalwan, D.K. 2018. Effect of Raised Bed Sowing of Pigeon Pea in Vertisols in Central Narmada Valley Agro-Climatic Zone of Madhya Pradesh, India. Int.J.Curr.Microbiol.App.Sci. 7(03): 2904-2906. doi: https://doi.org/10.20546/ijcmas.2018.703.335 